\title{
Baltic amber harvestman types (Arachnida: Opiliones: Eupnoi and Dyspnoi)
}

\author{
Jason A. Dunlop* \\ Museum für Naturkunde der Humboldt-Universität zu Berlin, Invalidenstraße 43, D-10115 Berlin, Germany
}

Received 15 November 2005, accepted 24 January 2006

Published online 17 July 2006

With 6 figures

Key words: Arachnida, Opiliones, Eupnoi, Dyspnoi, Baltic amber, Palaeogene, biogeography.

\begin{abstract}
Baltic amber eupnoid and dyspnoid types (Arachnida: Opiliones) in the Berendt collection are redescribed from their repository in the Museum für Naturkunde, Berlin. Type specimens of Caddo dentipalpis (Koch \& Berendt, 1854), Dicranopalpus ramiger (Koch \& Berendt, 1854), Nemastoma (?) incertum Koch \& Berendt, 1854, Mitostoma (?) denticulatum (Koch \& Berendt, 1854) and Histricostoma (?) tuberculatum (Koch \& Berendt, 1854) are all redescribed and the first photographs and camera lucida drawings of this material are presented. $N$. (?) incertum is removed from synonymy with $M$. (?) denticulatum. The status of the other Baltic amber harvestman types and their affinities are discussed. The type of Sabacon bachofeni Roewer, 1939 (= S. claviger (Menge, 1854)) held in the Bavarian State collection, Munich is also redescribed here, but the repository of three other Roewer harvestman types and all of Menge's types remains uncertain. The problematic Cheiromachus coriaceus Menge, 1854 is considered a nomen dubium, as is Phalangium succineum Presl, 1822, which may not even be a harvestman.
\end{abstract}

Schlüsselwörter: Arachnida, Opiliones, Eupnoi, Dyspnoi, Paläogen, Baltischer Bernstein, Biogeographie, Weberknechte, Spinnentiere.

\section{Zusammenfassung}

Typenmaterial der Weberknecht-Gruppen Eupnoi und Dyspnoi (Arachnida: Opiliones) vom Baltischen Bernstein aus der Berendt-Sammlung des Museums für Naturkunde Berlin wurde bearbeitet. Dabei wurde das Typusmaterial von Caddo dentipalpis (Koch \& Berendt, 1854), Dicranopalpus ramiger (Koch \& Berendt, 1854), Nemastoma (?) incertum Koch \& Berendt, 1854, Mitostoma (?) denticulatum (Koch \& Berendt, 1854) und Histricostoma (?) tuberculatum (Koch \& Berendt, 1854) revidiert und die ersten Fotografien und camera lucida-Zeichnungen dieses Materials hergestellt. N. (?) incertum wurde aus der Synonymie von $M$. (?) denticulatum herausgenommen. Der Status der anderen Weberknecht Typen aus dem Baltischen Bernstein und ihre Stellung werden diskutiert. Sabacon bachofeni Roewer, 1939 (= S. claviger (Menge, 1854)) wird anhand des Holotypus aus der Bayerischen Staatssammlung München wiederbeschrieben. Der Aufbewahrungsort dreier weiterer Weberknecht-Typen von Roewer und sämtlicher Typen von Menge bleibt weiterhin unklar. Der problematische Cheiromachus coriaceus Menge, 1854 wird als nomen dubium interpretiert; gleiches gilt für Phalangium succineum Presl, 1822, welcher vielleicht gar kein Weberknecht ist.

\section{Introduction}

Amber is the richest source of fossil harvestmen (Arachnida: Opiliones); see Dunlop (in press) for a review and further literature. Most of the known inclusions come from Baltic amber, which is now usually assigned to an Eocene age (c. 44$49 \mathrm{Ma})$. Baltic harvestman inclusions were ori-

* e-mail: jason.dunlop@museum.hu-berlin.de 
ginally described by Koch \& Berendt (1854), Menge (1854) and Roewer (1939). A further, widely overlooked, name was published by Presl (1822). It should also be mentioned that Berendt (1830) assigned some Baltic amber inclusions to Phalangium cancroides (Linnaeus, 1758) - which is in fact a Recent pseudoscorpion, currently in the genus Chelifer Geoffroy, 1762 - and to the common, Recent harvestman, Phalangium opilio Linnaeus, 1761. Although listed as an inclusion by Scudder (1891:279), this sole example of an amber fossil assignable to a living harvestman species has not been substantiated in subsequent work and is probably erroneous.

Baltic amber harvestmen were reviewed by Staręga (2002) based on material in Polish collections. He recognised nine valid species (Presl's name was missed), two of which he considered hard to place systematically. While Staręga's conclusions can be largely supported, he did not make reference to the important type material of Koch \& Berendt (1854) held in Berlin. Examination of these types revealed that the original authors' illustrations are in fact reconstructions and differ, sometimes significantly, from the way these name-bearing specimens appear in the matrix. This means that subsequent authors who have proposed transfers or synonymies (Bishop \& Crosby 1924; Petrunkevitch 1955; Staręga 1976, 2002) have done so based on somewhat idealised pictures of the animals. Koch \& Berendt's original material is very old and its condition is in some cases poor (see below). Here the first photographs and camera lucida drawings of all the available Koch \& Berendt's harvestman type species are offered as a basis for future work on Palaeogene-Neogene amber Opiliones, along with the one traceable Roewer (1939) type. Much undescribed material exists from both Baltic amber (e.g. Larsson 1978; Weitschat \& Wichard 2002, pl. 12) and the German Bitterfeld amber (see also Dunlop \& Giribet 2003).

The single Baltic amber laniatorid harvestman a predominantly southern hemisphere clade was recently redescribed and assigned to a new (fossil) genus, Proholoscotolemon Ubick \& Dunlop, 2005, probably closely related to the extant European cladonychiid Holoscotolemon Roewer, 1915. The present paper complements this work by focusing on the remaining harvestman suborders recorded from Baltic amber, i.e. Eupnoi and Dyspnoi. These include the typical 'daddy longlegs' type of harvestmen found widely across the Palaearctic today.

\section{Material and methods}

\section{Koch \& Berendt's types}

Berendt (1845) noted that some of the amber material he was working on was in the "Mineralien-Kabinet" of Berlin. In the same paper he listed species names from the forthcoming (Koch \& Berendt 1854) study, rendering the 1845 names nomen nuda without diagnoses, figures or indications. The "Mineralien-Kabinet" was part of the FriederichWilhelm (later the Humboldt) University in Berlin and was eventually combined at the end of the $19^{\text {th }}$ century with the Zoologisches Museum Berlin to form the present Museum für Naturkunde Berlin (MfN). Despite Petrunkevitch's (1958, p. 103) claim (at least for spiders) that the important type collections of both Koch \& Berendt and Menge were lost, all except one of Koch \& Berendt's harvestman types were recently confirmed as being in the MfN. Keilbach (1982) explicitly listed these inclusions as Berlin specimens under the unusual acronym "NPB", specifying them as either "Original Berendt" or, in one case, "Coll. Kühl". The harvestmen were also listed under both their original and current names by Spahr (1993).

The Berendt fossils were formally purchased in 1873 and are associated with hand-written labels indicating the original name and the relevant figure from the 1854 publication. There are also repository numbers (listed below), possibly added later as they are in a different ink colour and style to the rest of the label. These older numbers should not be confused with a modern numbering scheme introduced for the fossil arthropod collection in Berlin under the acronym MB.A. Koch \& Berendt's material is over 150 years old. The amber has oxidised somewhat and is now rather dark which does not make the animals easy to photograph. Frequently the amber has surface scratches or internal cracks, which occasionally obscure the inclusion. In some cases the amber is quite brittle, fractured or even broken. Specimens were photographed using a microscope-attached Canon Power Shot G6 digital camera and processed using Adobe Photoshop ${ }^{\circ}$, and drawn with a camera lucida attachment on a Leica MZ12 stereomicroscope. The fossils were compared to extant material in the Berlin collections and the literature - especially Martens' (1978) excellent summary of extant central European harvestmen. Familial and generic nomenclature follows the online catalogue of Kury (2003).

Unfortunately, the type material of one species cited to "Coll. Kühl." - Opilio ovalis Koch \& Berendt, 1854 - could not be found in a recent search of the Kühl collection in Berlin. This is despite the fact that Keilbach (1982) marked it with a "+" in his paper to indicate that he had personally seen the specimen during a tour of museum collections in 1979. The present whereabouts of the type remains unclear and it may have been misplaced. Kühl's amber collection was purchased by the Berlin museum in 1888 and while there are some fairly old arachnid types (e.g. mites) among it, no harvestmen were found with labels, or other indications, that they might be Koch \& Berendt's original material dating from the middle of the $19^{\text {th }}$ century.

\section{Menge's types}

Koch \& Berendt's (1854) study was posthumously published by Anton Menge from Danzig who also described additional species (Menge 1854) as footnotes to this paper. Crawford (1992, p. 15) implied that Menge's (1854) harvestman types are also in Berlin, but they could not be found in this collection. Indeed Menge's material is cited as having been in the Westpreußische Provinzialmuseum, Danzig (= Gdańsk, Poland); see e.g. Bronn (1853-1856). After the war the Gdańsk material seems to have become split up. Traces of it can be found in the Museum of the Earth in Warsaw (MZW), Po- 
land and the Natural History Museum of Leipzig, Germany (Kosmowska-Ceranowicz 2001). These institutes might include some of Menge's arachnid types (see also below), but this has proven difficult to confirm - especially given that Menge did not provide illustrations which can be directly compared with potential type material. Note that Keilbach (1982) also included the fossil Phalangopus subtilis Menge, 1854 under Opiliones, but this taxon was listed by Petrunkevitch (1955) as Araneae incertae sedis and by Scudder (1891) and Bonnet (1958) under Scytodidae (spitting spiders). It is not considered to be a harvestman here.

\section{Roewer's types}

The types of the four species described by Roewer (1939) were part of a collection belonging to Adolf Bachofen-Echt from Mödling near Vienna, Austria. A museum repository is not given in this original paper. Keilbach (1982) cited them all as being in the Naturwissenschaftliche Sammlung des Bayerischen Staates, Munich, Germany (NSBS) - all with Bachofen-Echt collection numbers (see below). However, Keilbach but did not mark them with a "+ " in his list which means he did not check this repository personally. The types of Sabacon bachofeni Roewer, 1939 have been confirmed as being in the NSBS (H. Mayr, pers. comm. 2004), but unfortunately Roewer's other three species could not be traced in this collection during a recent search and may not have been deposited there at all (contra Keilbach). They could not be traced in another known repository of Bachofen-Echt's material in the Palaeontological Institute of the University of Vienna (N. Vávra, pers. comm. 2002) either, thus the whereabouts of the three missing types remains uncertain. Staręga $(1976,2002)$ treated all of Roewer's species names as junior synonyms and this conclusion is supported here.

\section{Systematic palaeontology}

Order Opiliones Sundevall, 1833

Suborder Eupnoi Hansen \& Sørensen, 1904

Family Caddidae Banks, 1893

Subfamily Caddinae Banks, 1893

Remarks. The publication date of Caddidae is sometimes given as Banks (1892), but in this initial paper only the genus Caddo Banks, 1892 was proposed. The first indication of a suprageneric taxon is Banks (1893: 207) who proposed a tribe Caddini.

\section{Caddo Banks, 1892}

\section{Caddo dentipalpus (Koch \& Berendt, 1854)}

Figs 1A, 2A

1845 Platybunus dentipalpus Berendt: 872. (nomen nudum)

1854 Platybunus dentipalpus Koch \& Berendt: 101-102, pl. 15: fig. 125.

1856 Platybunus dentipalpus. - Giebel: 476-477.

1885 Platybunus dentipalpus. - Scudder: 741, fig. 917.

1886 Platybunus dentipalpus. - Scudder: 740, fig. 934.

1891 Platybunus dentipalpus. - Scudder: 283.

1924 Caddo dentipalpus. - Bishop \& Crosby: 83-84.
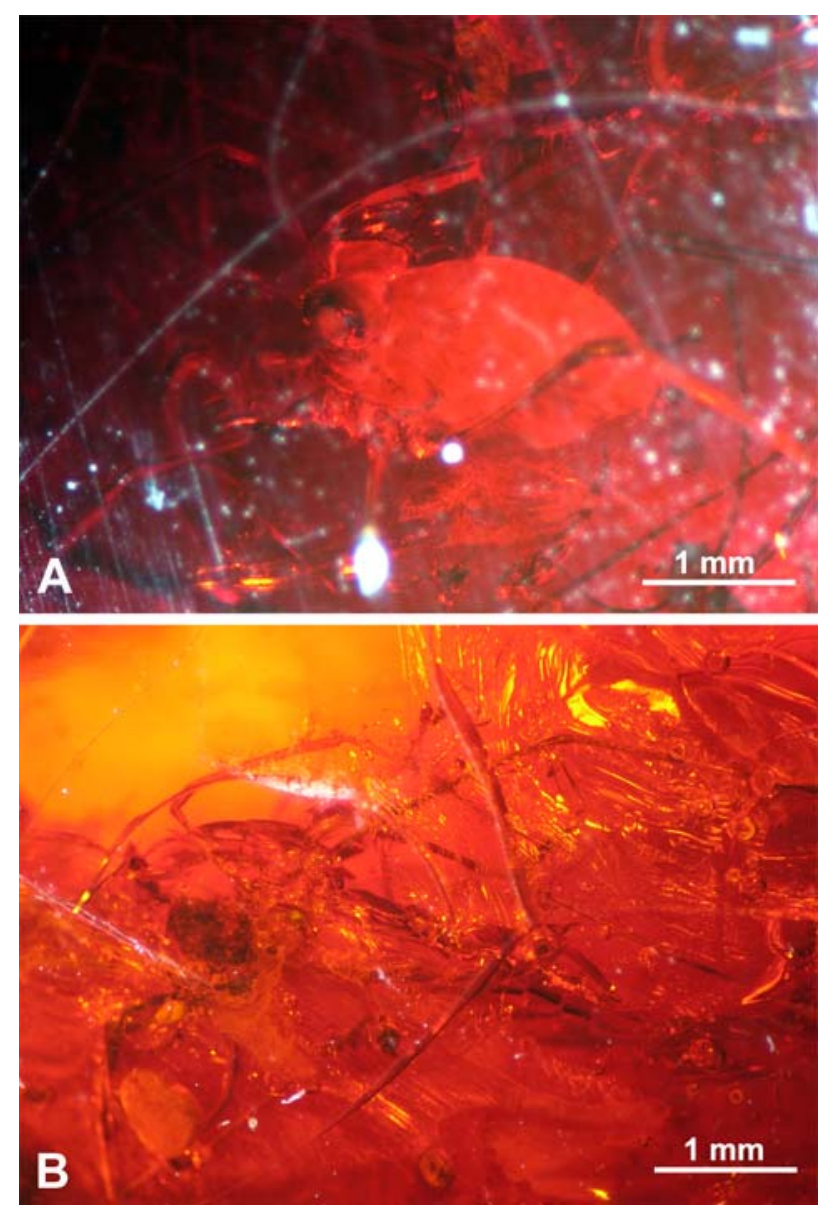

Fig. 1. A - Caddo dentipalpis (Koch \& Berendt, 1854), holotype (MfN, Berendt collection, repository nr. 7340), Baltic amber (Palaeogene: Eocene); B - Dicranopalpus ramiger (Koch \& Berendt, 1854), holotype (MfN, Berendt collection, repository nr. 7250), Baltic amber (Palaeogene: Eocene).

1955 Caddo dentipalpus. - Petrunkevitch: 85, fig. 53(1).

1962 Caddo dentipalpus. - Dubinin: 481, fig. 1382.

1975 Caddo dentipalpus. - Shear: 69.

1976 Caddo dentipalpus. - Staręga: 46.

1982 Platybunus dentipalpus. - Keilbach: 190.

1993 Caddo dentipalpus. - Selden: 306.

1993 Platybunus dentipalpus. - Spahr: 22.

1993 Caddo dentipalpus. - Spahr: 20.

2001 Caddo dentipalpus. - Kupryjanowicz: 24, photo 3. 2002 Caddo dentipalpus. - Staręga: 602, 604, fig. 2.

Holotype. MfN, Berendt collection, repository number 7340 .

Type locality and horizon. Baltic amber (Palaeogene, Eocene); precise locality unclear.

Diagnosis. Fossil caddid with three large megaspines on the ventral surface of the palpal femur and a small spinose, mesal apophysis at the distal end of the femur.

Description. Body oval, compact with fairly clear demarcation between carapace and dorsal surface of opisthosoma. Total body length c. $2.3 \mathrm{~mm}$; maximum (dorso-ventral) thickness c. $1.3 \mathrm{~mm}$. Opisthosoma smooth with some hints of segmental boundaries, narrowing posteriorly to form a distinct anal region. Eyes massive, maximum diameter $0.58 \mathrm{~mm}$, forming two lobes 
which dominate the carapace region. Chelicerae present, but poorly resolved. Pedipalpal femora with three prominent megaspines on ventral surface. Femur also bears mesal, spinose apophysis towards the distal end with short, inward-pointing spines. Remaining pedipalpal articles quite setose. Article lengths: femur $0.61 \mathrm{~mm}$, patella $0.43 \mathrm{~mm}$, tibia and tarsus also about the same, but boundary between them obscured. Pedipalp ends in single, gently curving claw. Legs relatively complete, elongate and slender, with short patellae. Leg articles occasionally preserving one or two short setae. Leg 2 on left side missing. Legs often fragmentary or partly obscured making accurate measurements difficult, however, leg 1 c. $6 \mathrm{~mm}$ long in total.

Remarks. This is one of the most instantly recognisable amber harvestman. Bishop \& Crosby (1924) transferred Platybunus dentipalpus Koch \& Berendt, 1854 to Caddo Banks, 1892 based on the large and highly characteristic eyes. However, it should be mentioned that juveniles of other eupnoid harvestmen can have proportionately large eyes and care must be taken not to confuse inclusions of young animals with caddids. The species name dentipalpus also alludes to a further typical caddid character: a dentate palpal femur (see Diagnosis). In not accepting this transfer Keilbach (1982) appears to have been unaware of the Bishop \& Crosby paper and does not cite it among his references. According to Shear (1975) two subfamilies, Caddinae (with a single genus Caddo) and Acropsopilioninae Roewer, 1923, can be recognised. The left palp in the holotype is overlain by an adjacent leg which obscures the precise podomere boundary, but this specimen is suggestive of an explicit character of Caddo; namely a palpal tarsus at least as long as - if not longer than - the tibia (cf. Shear 1975). Thus Bishop \& Crosby's transfer can be accepted. Additional material from Baltic amber has recently come to light and a particularly fine example from the Giecewicz collection in Warsaw was figured by Kupryjanowicz (2001) and Staręga (2002). There are also examples of this species in the German Bitterfeld amber (Dunlop, unpublished observation).

Following Bishop \& Crosby's account, Shear (1975: 73) went so far as to suggest that Caddo dentipalpus is very similar to - perhaps even conspecific with - the extant North American species Caddo agilis Banks, 1892. In any case the fossil form is of particular interest given that there are no Recent records of the family in Europe, or much of Asia for that matter. According to revision of Shear (1975) Caddidae is currently restricted to North America, Mexico, Chile, Japan, Australia, New Zealand and South Africa. Like these amber inclusions, the genus Caddo is restricted today to the northern hemisphere. Baltic amber shows that it used to occur more widely, being present in north-central Europe during the Palaeogene, but that it subsequently became extinct in this region.

\section{Family Phalangiidae Latreille, 1802}

\section{Dicranopalpus Doleschall, 1852}

\section{Dicranopalpus ramiger (Koch \& Berendt, 1854)} Figs 1B, 2B-C

1845 Opilio ramiger Berendt: p. 872. (nomen nudum) 1854 Opilio ramiger Koch \& Berendt: 100-101, pl. 12: fig. 100.

1854 Opilio corniger Menge: 101.

1856 Opilio ramiger. - Giebel: 476.

1856 Opilio corniger. - Giebel: 476.

1891 Opilio ramiger. - Scudder: 278.

1891 Opilio corniger. - Scudder: 277.

1939 Dicranopalpus palmnickensis Roewer: 1-2.

1955 Dicranopalpus ramiger. - Petrunkevitch: 86, fig. 53(2).

1962 Dicranopalpus ramiger. - Dubinin: 481, fig. 1381.

1976 Dicranopalpus ramiger. - Staręga: 46, fig. 79.

1976 Opilio corniger. - Staręga: 46.

1976 Dicranopalpus palmnickensis. - Staręga: 46.

1982 Opilio ramiger. - Keilbach: 190.

1982 Opilio corniger. - Keilbach: 191. (as a nomen nudum)

1982 Dicranopalpus palmnickensis. - Keilbach: 190.

1993 Dicranopalpus ramiger. - Selden: 306.

1993 Dicranopalpus palmnickensis. - Selden: 306.

1993 Opilio ramiger. - Spahr: 22.

1993 Dicranopalpus ramiger. - Spahr: 21.

1993 Opilio corniger. - Spahr: 22.

1993 Dicranopalpus palmnickensis. - Spahr: 21.

2002 Dicranopalpus ramiger. - Staręga: 602-604, fig. 3.

2002 Opilio corniger. - Starega: 603-604.

2002 Dicranopalpus palmnickensis. - Staręga: 603-604.

Holotype. MfN, Berendt collection, repository number 7250 (holotype of $O$. ramiger). Holotype of $O$. corniger formally in Danzig (=Gdańsk, Poland); current whereabouts unknown. Type material of D. palmnickensis cited as NSBS (Bachofen-Echt collection, numbers 144, 149, 154); its presence could not be confirmed in a recent search.

Type locality and horizon. Baltic amber (Palaeogene, Eocene); precise locality unclear.

Diagnosis. Fossil Dicranopalpus with a setose patellar apophsis a little over twice the length of the main body of the patella.

Description. Body oval, compact, length c. $1 \mathrm{~mm}$, maximum width c. $0.6 \mathrm{~mm}$. Details (eyes, segmentation, ornament) of body equivocal. Mouthparts equivocal. Pedipalp elongate with slender articles. Pedipalpal femur length at least $0.46 \mathrm{~mm}$, patellar $0.22 \mathrm{~mm}$, tibia at least $0.60 \mathrm{~mm}$; but distal end of tibia obscure. Patella with prominent, highly setose mesal apophysis, length $0.50 \mathrm{~mm}$. Legs slender and elongate with 

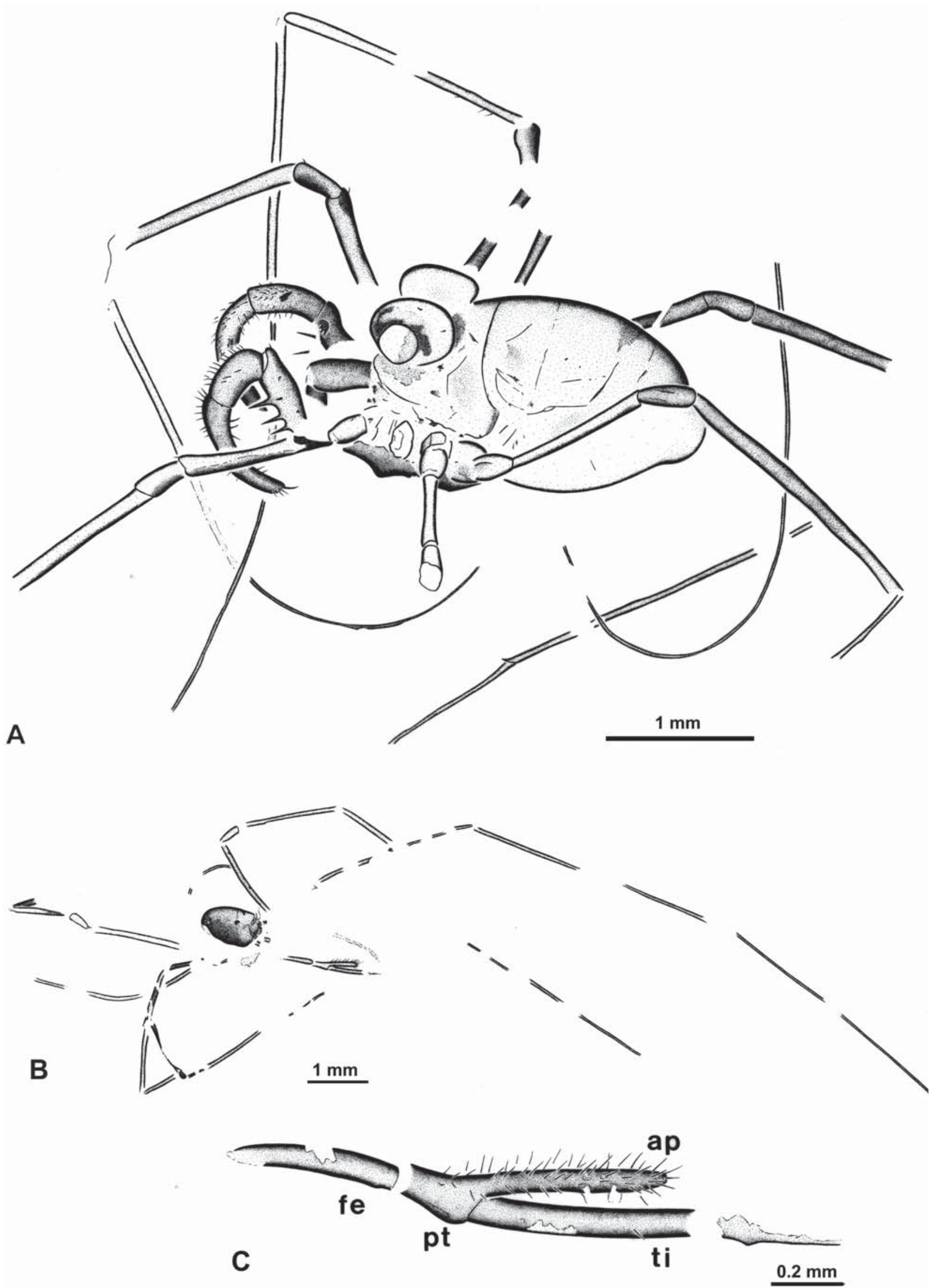

Fig. 2. A - Caddo dentipalpis (Koch \& Berendt, 1854), camera lucida drawing of the holotype; B - Dicranopalpus ramiger (Koch \& Berendt, 1854), camera lucida drawing of the holotype, overview; C - detail of the D. ramiger pedipalp (fe - femur; pt - patella; ap - patellar apophysis; ti - tibia). 
short patellae. Leg 2 longest, at least $13 \mathrm{~mm}$ long. Leg 3 with podomere lengths: femur $1.28 \mathrm{~mm}$, patella $0.36 \mathrm{~mm}$, tibia $1.64 \mathrm{~mm}$. Ventral surface unknown.

Remarks. This is another easily recognisable amber harvestman species. However, the holotype is actually quite a poor example which preserves the body and legs only in outline and is difficult to see in the matrix. It does show the characteristic Dicranopalpus Doleschall, 1852 patellar apophysis (cf. Martens 1978, figs. 704-706). However, this is essentially diagnostic for the whole (Paleogene-Recent) genus and the holotype offers little in the way of useful species characters. As with Caddo (see above), Keilbach (1982) either did not accept, or was unaware of, Petrunkevitch's (1955) earlier transfer of O. ramiger Koch \& Berendt to Dicranopalpus. Given the unmistakable shape of the patellar apophysis this transfer is entirely justified.

Staręga $(1976,2002)$ briefly synonymised both Opilio corniger Menge, 1854 and Dicranopalus palmnickensis Roewer, 1939 with D. ramiger. In his original description Menge (1854:101) referred to $O$. corniger as a "closely related" species which he even admitted might simply be a male - diagnosed by an additional short apophysis at the end of the pedipalpal tiba. This second apophysis is not shown in Koch \& Berendt's drawing of $D$. ramiger. Its absence is unsurprising given the poor quality of the D. ramiger holotype, which is unfortunately equivocal on this character (Fig. 2C). All other figured Dicranopalpus material in amber (e.g. Weitschat \& Wichard 2002, pl. 12a; Staręga 2002, fig. 3) shows this second, smaller, setose apophysis at the distal end of the tibia and given the condition of the holotype its presence or absence is a poor diagnostic character between the first two described species. $O$. corniger was listed, without explanation, by Keilbach (1982) as a nomen nudum, but following Staręga it is accepted here as a junior synonym of D. ramiger. The synonymy of D. palmnickensis also appears justified given that Roewer (1939) described a juvenile and - as with his other amber fossils - did not even mention the previously described species Roewer noted the characteristic (but genus-specific) apophysis on the pedipalp, yet did not figure his material and offered little in the way of a species-specific diagnosis. Published photographs and examination of unpublished Baltic and Bitterfeld material in Berlin does not suggest, thus far, the presence of more than one fossil Dicranopalpus species in amber; see also comments in
Staręga (2002), who further noted that many records are of juveniles.

The presence of Dicranopalpus in Baltic amber is notable given that this genus is predominantly found today in North Africa and southern Europe. As with many amber taxa, it suggest a previously much wider distribution. Interestingly, one extant - albeit somewhat aberrant - species, Dicranopalpus ramosus (Simon, 1909), is currently spreading northwards through Europe; apparently at some speed (e.g. Hillyard 2004) and probably with human help. It is interesting to speculate whether these southern faunal elements repeatedly spread north during warmer time intervals - like the time of the Baltic amber forest - only to be killed off or driven back during colder (e.g. glacial) periods. However most European Dicranopalpus species are highly specialised subalpine to alpine species with little capacity for extending their range (Jochen Martens, pers. comm. 2005).

Family ?Phalangiidae Simon, 1879

\section{Opilio ovalis Koch \& Berendt, 1854}

1845 Opilio ovalis Berendt: 872. (nomen nudum)

1854 Opilio ovalis Koch \& Berendt: 99-100, pl. 12: fig. 99.

1856 Opilio ovalis. - Giebel: 476.

1891 Opilio ovalis. - Scudder: 277.

1955 Opilio ovalis. - Petrunkevitch: 86.

1976 Opilio ovalis. - Staręga: 46.

1982 Opilio ovalis. - Keilbach: 190

1993 Opilio ovalis. - Selden: 306.

1993 Opilio ovalis. - Spahr: 22.

2002 Opilio ovalis. - Staręga: 604.

Holotype. Cited as being in the Kühl amber collection in the MfN Berlin. Could not be traced in a recent (2005) search.

Type locality and horizon. Baltic amber (Palaeogene, Eocene); precise locality unclear.

Re marks. Staręga (2002) regarded the systematic position of this species as uncertain. Given the slight unreliability of the original illustrations, it would be unwise to comment further on the affinities of this fossil until the type can be relocated.

Family Sclerosomatidae Simon, 1879

\section{Leiobunum C. L. Koch, 1839}

\section{Leiobunum longipes Menge, 1854}

1854 Leiobunum saparum Menge: 8. (? lapsus) 1854 Leiobunum longipes Menge: 102. 
1856 Leiobunum longipes. - Giebel: 477.

1891 Leiobunum longipes. - Scudder: 269.

1939 Liobunum inclusum Roewer: 2.

1955 Liobunum longipes. - Petrunkevitch: 86

1982 Leiobunum longipes. - Keilbach: 190.

1982 Leiobunum inclusum. - Keilbach: 190.

1993 Liobunum saparum. - Selden: 306.

1993 Liobunum longipes. - Spahr: 20.

1993 Liobunum inclusum. - Spahr: 20.

2002 Leiobunum longipes. - Staręga: 602-604, fig. 2.

2002 Leiobunum inclusum. - Staręga: 603.

Holotype. Holotype of L. longipes probably originally in Danzig (= Gdańsk, Poland), current whereabouts unknown. Type material of L. inclusum cited as NSBS (Bachofen-Echt collection, numbers 51,181); its presence could not be confirmed in a recent search.

Type locality and horizon. Baltic amber (Palaeogene, Eocene); precise locality unclear.

Remarks. The original description of Leiobunum longipes Menge, 1854 is extremely vague and barely qualifies as an indication. Menge simply mentioned one specimen in his possession under this name in which the second pair of legs was (diagnostically) about twenty times longer than the body. Furthermore, in the introduction to this paper he listed a different species (this time without any sort of description or indication) under the name Leiobunum saparum Menge, 1854. This name was picked up by Selden (1993), but appears to be a lapsus; whereby two names (longipes and saparum) were accidentally used for a single specimen. Only L. longipes is associated with something approximating towards a description and should therefore be accepted as the valid name. It is the senior homonym of a living harvestman species; see Cokendolpher (1984) for a clarification and a discussion of Leiobunum C. L. Koch, 1839 and its unjustified amendment to Liobunum.

Staręga (2002) figured only a chelicera, but commented on the fact that this species is easily recognisable and represents both the largest and most common harvestman in the Baltic amber fauna. He recognised only one Leiobunum species in Baltic amber and regarded Menge's name as the senior synonym of Leiobunum inclusum Roewer, 1939. The type of the latter was described by Roewer as having a body length of $2.3 \mathrm{~mm}$, a shiny, flat ocular tubercle lacking ornament and unmodified pedipalps with a comb-like distal claw and no apophyses on the patella and tibia.
Suborder Dyspnoi Hansen \& Sørensen, 1904
Family Sabaconidae Dresco, 1970

Sabacon Simon, 1879

Sabacon claviger (Menge, 1854)

Figs 3A, 4A-B

1854 Nemastoma clavigerum Menge: 99.

1856 Nemastoma clavigerum. - Giebel: 475.

1891 Nemastoma clavigerum. - Scudder: 274.

1939 Sabacon bachofeni Roewer: 4-5, fig. 2.

1955 Sabacon bachofeni. - Petrunkevitch: 85.

1976 Nemastoma clavigerum. - Staręga: 46.

1976 Sabacon bachofeni. - Staręga: 46.

1982 Nemastoma clavigerum. - Keilbach: 191.

1982 Sabacon bachofeni. - Keilbach: 191.

1993 Nemastoma clavigerum. - Selden: 306.

1993 Nemastoma clavigerum. - Spahr: 21.

1993 Sabacon bachofeni. - Spahr: 23.

2002 Sabacon claviger. - Staręga: 602-603, fig. 1.

2002 Sabacon bachofeni. - Staręga: 603.

Holotype. Holotype of $N$. clavigerum formally in Danzig (= Gdańsk, Poland), current whereabouts unknown. However, Staręga (2002) examined an MZW specimen (MZW 469/124)
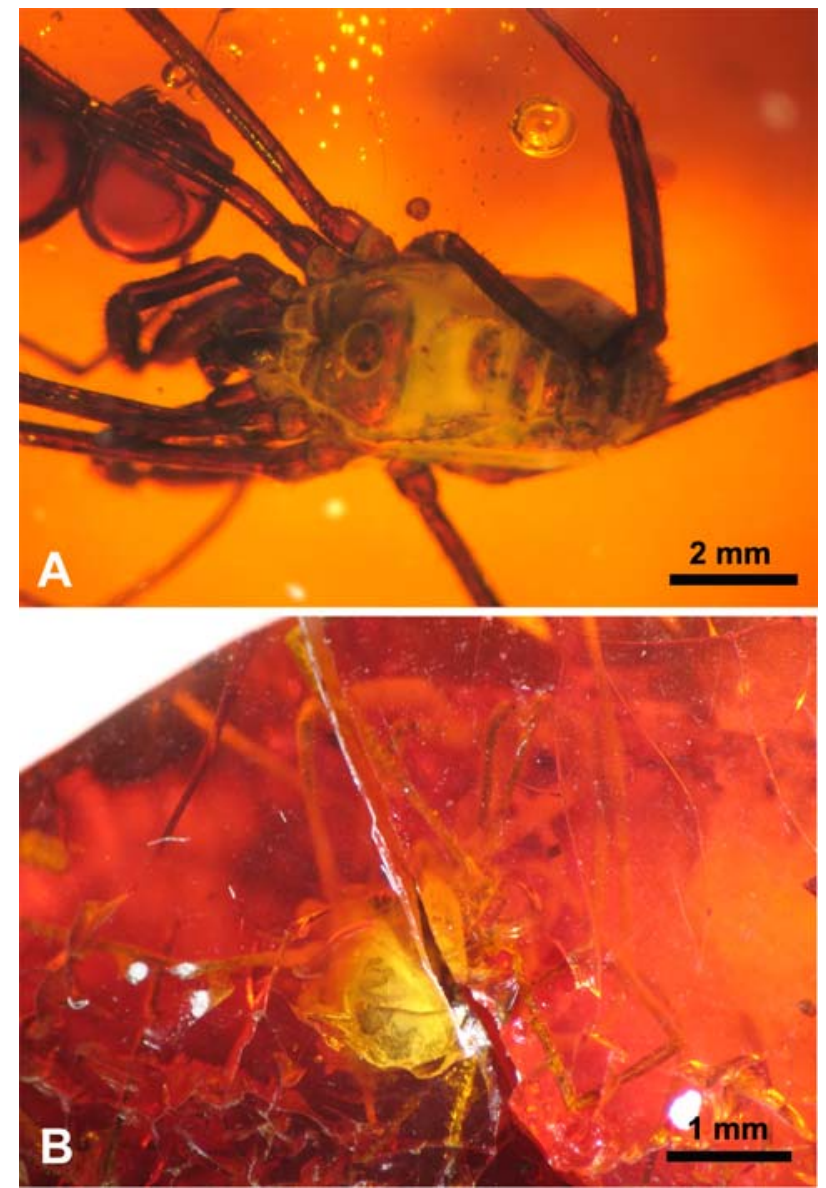

Fig. 3. A - Sabacon claviger (Koch \& Berendt, 1854), holotype of its junior synonym Sabacon bachofeni Roewer, 1939 (NSBS, Bachofen-Echt collection nr. 110), Baltic amber (Palaeogene: Eocene); B - Nemastoma (?) incertum Koch \& Berendt, 1854, holotype (MfN, Berendt collection, repository nr. 7252), Baltic amber (Palaeogene: Eocene). 

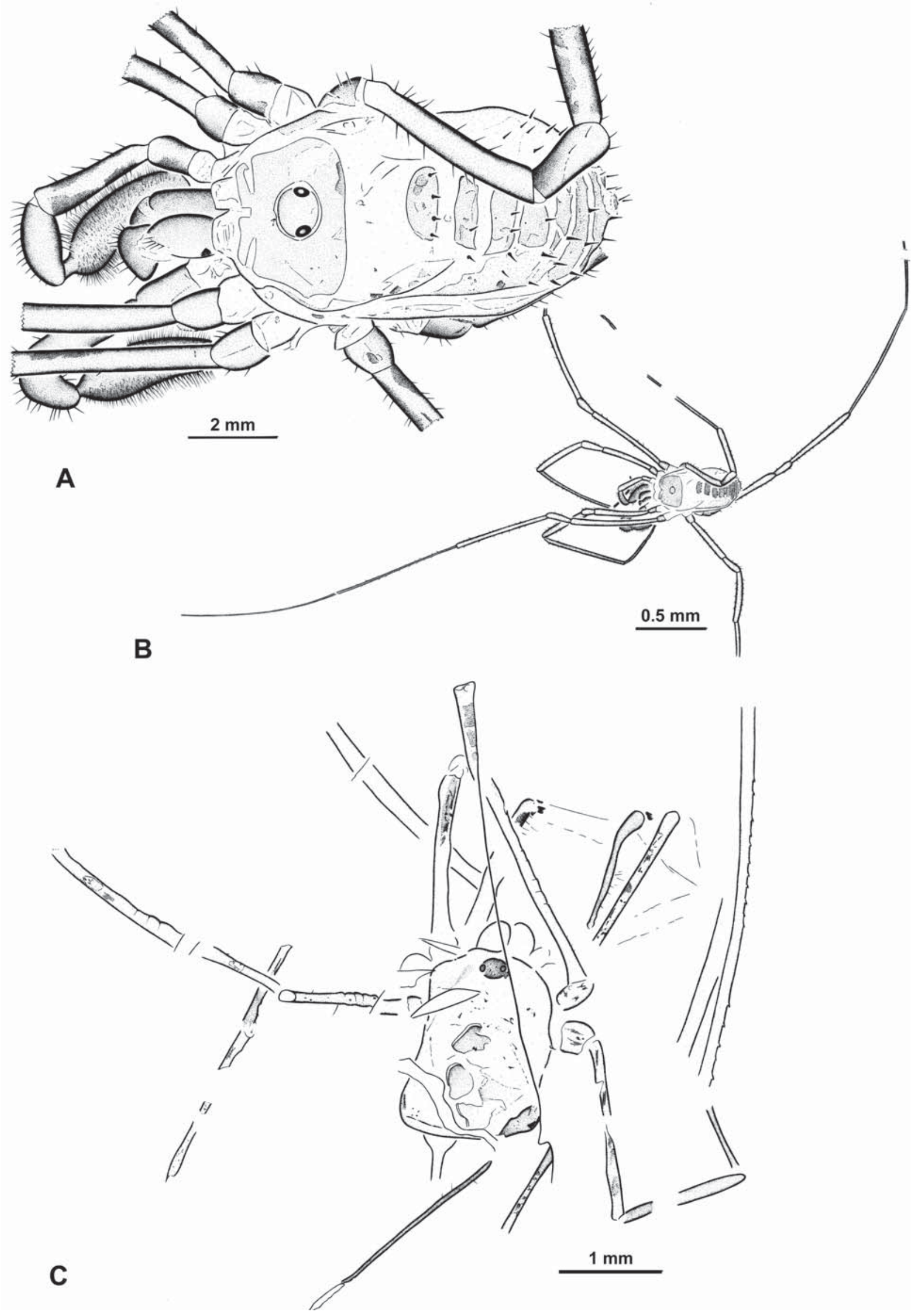

Fig. 4. A - Sabacon claviger (Koch \& Berendt, 1854), camera lucida drawing of the holotype of its junior synonym Sabacon bachofeni Roewer, 1939, detail; B - overview of body; C - Nemastoma (?) incertum Koch \& Berendt, 1854, camera lucida drawing of the holotype. 
from the pre-war Gdańsk collection and noted that it could have been from among the material seen by Menge himself. Whether this material should be treated as a lecto- or neotype requires further research into the fate of the original Gdańsk collection. Type material of S. bachofeni confirmed as being in the NSBS, Bachofen-Echt collection numbers 110 (figured here) and 142.

Type locality and horizon. Baltic amber (Palaeogene, Eocene); precise locality unclear.

Diagnosis. Fossil Sabacon with relatively elongate legs compared to modern species, leg 2 about seven times body length.

Description. Body oval, with little external differentiation into prosoma and opisthosoma. Maximum length $2.3 \mathrm{~mm}$, maximum width $1.2 \mathrm{~mm}$. Carapace trapezoidal, length $0.6 \mathrm{~mm}$, maximum width $0.9 \mathrm{~mm}$. Carapace with paired, narrow lateral indents towards the anterior margin and a central ocular tubercle. Opisthosoma largely unsclerotised but, tergites form discrete ovoid to quadratic sclerites which become wider and shorter posteriorly and are ornamented by regular rows of short thorns. Chelicerae and pedipalps robust. Chelicerae bear numerous strong setae. Pedipalps swollen distally with characteristic dense setation for the genus, especially on the tarsus. Legs elongate, fairly slender, with short setae along much of their length, femur-tibia noticeably wider than the more distal articles. Leg 2 largely complete, at least $14 \mathrm{~mm}$ long, or c. seven times body length. Article lengths in detail in mm. Femur 1, 1.45; femur 2, 2.45; femur 3, 1.36; femur 4, 2.09. Patella 1, 0.36; patella 2, 0.72; patella 3,0.63; patella 4, 0.54. Tibia 1, 1.45, tibia 2, 2.63, tibia 3, 1.45; tibia 4, 2.1. Metatarsus 1, 3.63; Metatarsus 4, 3.32. Entire lengths and/or article boundaries of more distal elements equivocal.

Remarks. The fossil described here lacks a development on the chelicerae typically seen in mature males of European species, although some East Asian males of Sabacon also lack this protuberence (Jochen Martens, pers. comm. 2005), thus it is difficult to sex this specimen unequivocally. Staręga (1976) suggested that Sabacon bachofeni Roewer, 1939 is a junior synonym of Nemastoma clavigerum Menge, 1854. He formally synonymised them (Staręga 2002) under the combination Sabacon claviger; the change in species name being associated with a change in genus gender. Roewer's (1939, figs 2-4) photographs of his species are good and strongly support both this synonymy and the assignment of the species to Sabacon Simon, 1879. Both described species have a highly characteristic pedipalp with inflated, densely setose tibiae and tarsi.
However, as with Dicranopalpus (see above), this palpal morphology is effectively a generic character. The fossil amber species can potentially be defined on its legs which, according to Staręga (2002), are somewhat longer than in living species (see also Figs 3A, 4A-B). Interestingly, modern Sabacon tend to occur in mountainous regions today (e.g. the Alps, Pyrenees and Apennines in Europe) and it was regarded by Martens (1978) as a Holarctic areal relict genus. Its presence in Baltic amber appears further north than its modern distribution.

\section{Family Nemastomatidae Simon, 1879}

Remarks. Larsson (1978) commented on the relative frequency with which nemastomatid harvestmen are found in Baltic amber. Note that the generic placements of all the fossil nemastomatids remain equivocal based on existing type specimens.

\section{Nemastoma (?) C. L. Koch, 1836}

\section{Nemastoma (?) incertum Koch \& Berendt, 1854} Figs 3B, 4C

1845 Nemastoma incertum Berendt: 872. (nomen nudum) 1854 Nemastoma incertum Koch \& Berendt 99, pl. 17: fig. 149.

1856 Nemastoma incertum. - Giebel: 475.

1891 Nemastoma incertum. - Scudder: 275.

1976 Nemastoma incertum. - Staręga: 46.

not 1976 Mitosoma denticulatum. - Staręga: 46.

1982 Nemastoma incertum. - Keilbach: 191.

1993 Nemastoma incertum. - Spahr: 21.

2002 Nemastoma incertum. - Staręga: 604. not 2002 Mitosoma denticulatum. - Staręga: 604.

Holotype. MfN, Berendt collection, repository number 7252 .

Type locality and horizon. Baltic amber (Palaeogene, Eocene); precise locality unclear.

Diagnosis. Fossil Nemastoma species lacking dorsal ornament of spines and tubercles.

Description. Body sub-quadrate, rounded anteriorly, with little external differentiation into prosoma and opisthosoma. Maximum length $1.8 \mathrm{~mm}$. Body widens slightly posteriorly, with a distinct posterior margin. Body covered by emulsion, but no ornament (spines, tubercles, etc.) protrudes through this film. Oval ocular tubercle close to anterior margin of body, maximum width $0.27 \mathrm{~mm}$. Chelicerae robust, but details poor; distal articles tucked under body. Pedipalps with elongate femora, but further details poor. Legs incomplete and partially disarticulated, but 
femora of anterior legs with at least three pseudoannulations. Disarticulated long leg article with distinct ornament of tiny thorns. Ventral surface unknown.

Remarks. The amber piece hosting the holotype has broken. The break, unfortunately, traverses the specimen through the body, but a reasonable drawing of it is still possible. The holotype is also largely covered with a white emulsion film which obscures some details. Starega (1976) tentatively, and (2002) formally, synonymised Nemastoma incertum Koch \& Berendt with Mitosoma denticulatum (Koch \& Berendt, 1854: see below), but did so without discussion or reference to the type material. The synonymy probably harks back to Menge (1854:99), who in his footnotes discussed the poor quality of Berendt's fossil and found little to distinguish it from M. denticulatum. However, on close examination $N$. incertum lacks any obvious ornament on the body (Figs 3B, 4C). The emulsion film is thin enough that spines or tubercles should be visible through it. No ornament comparable to that of M. denticulatum is present and thus $N$. incertum can be removed from synonymy. It could either be regarded as a valid species which can potentially be recognised by its general body shape, or as a nomen dubium which is too poorly-persevered to be assigned unequivocally. The absence of ornament could support retaining this species in Nemastoma C. L. Koch, 1836 , as in the original description, but this presumably plesiomorphic feature is not explicitly diagnostic for the genus. Furthermore, the legs in the holotype appear quite long compared to typical extant Nemastoma species (Axel Schönhofer, pers. comm. 2005) - which also tend to be deep leaf-litter forms. Additional comparative material may be needed to resolve the position and status of this fossil species.

\section{Mitostoma (?) Roewer, 1951}

\section{Mitostoma (?) denticulatum (Koch \& Berendt, 1854) Figs 5A, 6A-B}

1845 Nemastoma denticulatum Berendt: 872. (nomen nudum)

1854 Nemastoma denticulatum Koch \& Berendt: 98-99, pl. 11: fig. 98.

1856 Nemastoma denticulatum. - Giebel: 475.

1891 Nemastoma denticulatum. - Scudder: 274

1939 Nematoma succineum Roewer: 4, fig. 1.

1955 Nemastoma denticulatum. - Petrunkevitch: 85.

1976 Mitostoma denticulatum. - Staręga: 45-46, fig. 77.

1976 Nemastoma succineum. - Staręga: 46.

1982 Nemastoma denticulatum. - Keilbach: 191.
1993 Nemastoma denticulatum. - Selden: 306

1993 Nemastoma denticulatum. - Spahr: 21.

1993 Mitostoma denticulatum. - Spahr: 21.

1993 Nemastoma succineum. - Spahr: 21.

2002 Mitostoma denticulatum. - Staręga: 603

2002 Nemastoma succineum. - Starega: 603.

not 2002 Nemastoma incertum. - Staręga: 603.

Types. MfN, Berendt collection, repository number 7250 (syntypes). Better preserved example figured here and designated the lectotype; other specimen (not figured) the paralectotype. Holotype of N. succineum cited to the NSBS (Bachofen-Echt collection number 27), but could not be traced in a recent search.

Type locality and horizon. Baltic amber (Palaeogene, Eocene); precise locality unclear.

Diagnosis. Fossil Mitostoma with four rows of procurved processuli ancoriformis towards the front of the body; further ornament lacking.

Description. Lectotype. Relatively complete specimen, but missing much of the dorsal opisthosoma. No external differentiation into prosoma and opisthosoma. Body compact, oval, total length c. $2 \mathrm{~mm}$, maximum width c. $1.4 \mathrm{~mm}$. Ocular tubercle close to front end of body. Eye lenses small, separated by a series of small,
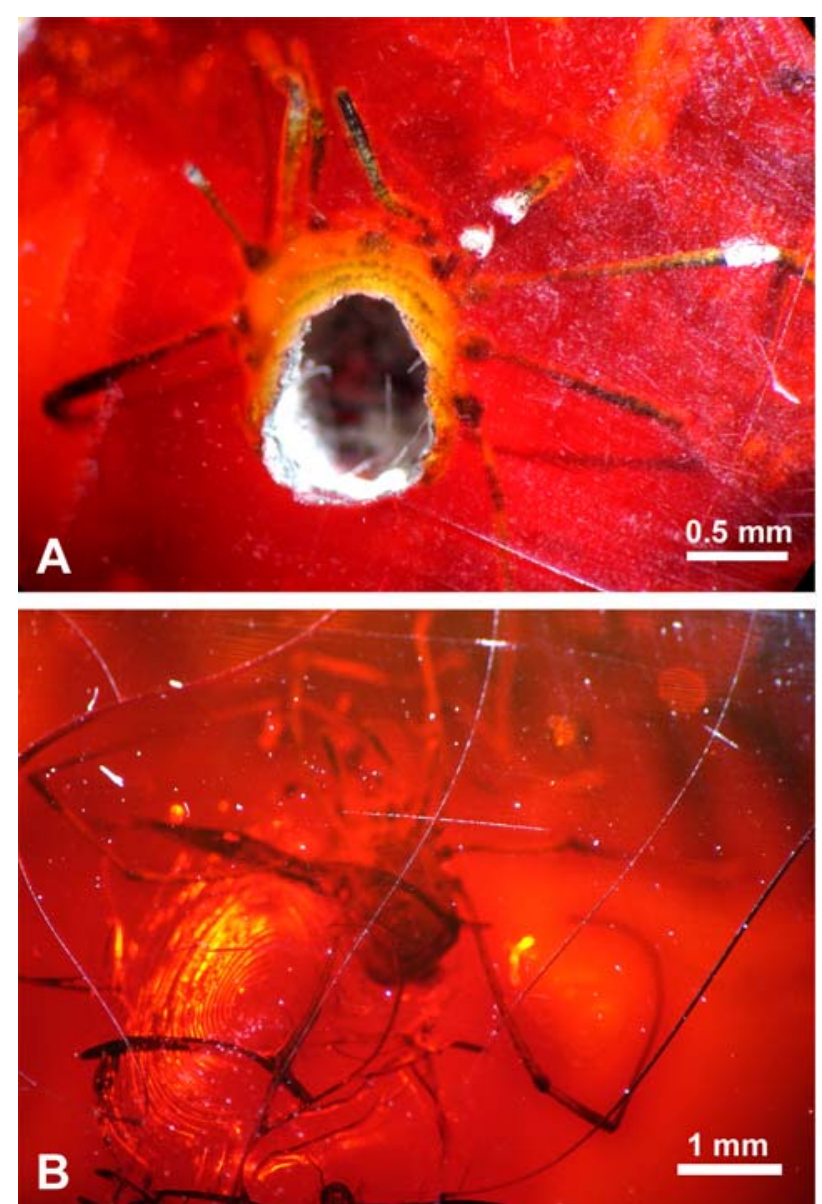

Fig. 5. A - Mitostoma (?) denticulatum (Koch \& Berendt, 1854), lectotype (MfN, Berendt collection, repository nr. 7250), Baltic amber (Palaeogene: Eocene); B - Histricostoma tuberculatum (Koch \& Berendt, 1854), holotype (MfN, Berendt collection, repository nr. 7248), Baltic amber (Palaeogene: Eocene). 


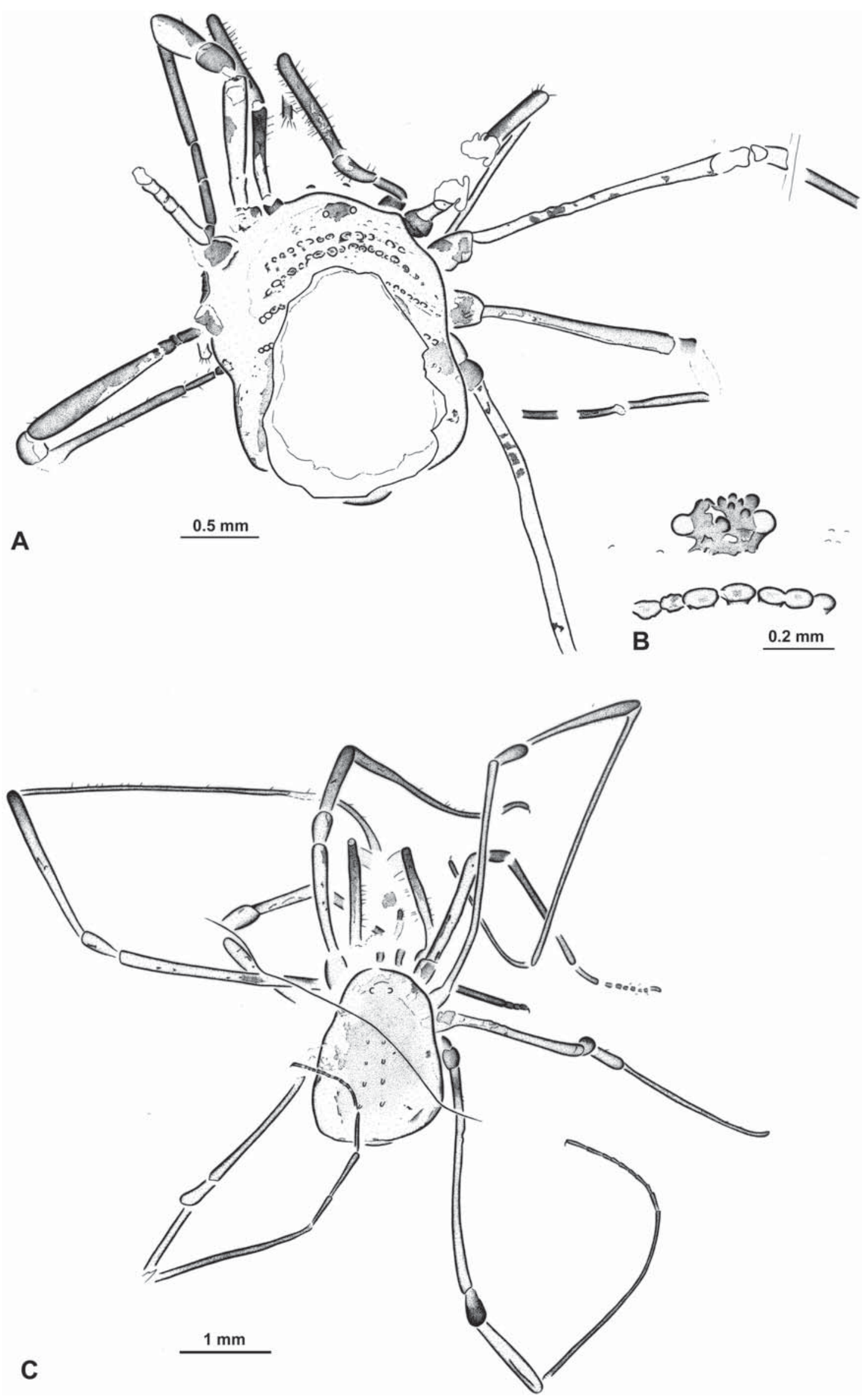

Fig. 6. A - Mitostoma (?) denticulatum (Koch \& Berendt, 1854), camera lucida drawing of the lectotype; B - ocular region and surrounding ornament; C - Histricostoma tuberculatum (Koch \& Berendt, 1854), camera lucida drawing of the holotype. 
rounded tubercles. Dorsal surface largely missing from opisthosomal region, but with ornament of at least four distinctly procurved rows of processuli ancoriformis, lacking any lateral connections between adjacent rows. First two rows quite closely packed, c. $0.1 \mathrm{~mm}$, together, third and fourth more widely separated, c. $0.2 \mathrm{~mm}$ from one another. Chelicerae unknown. Pedipalps long and slender. Distal end of femur and patella highly setose with characteristic inward facing and distally globose nemastomatid setae. Legs slender, femora 1-3 widen distally with lengths of 0.85 , 1.80 and $1.11 \mathrm{~mm}$ respectively. Femora 1 with weak, and femur 2 with pronounced, pseudoannulation. More distal podomeres less well preserved. Ventral opisthosoma segmented, but details poor.

Remarks. The original material associated with the old label consists of two specimens, both in circular pieces of amber with a hole through the middle. The figured specimen (Figs 5A, $6 \mathrm{~A}-\mathrm{B})$ - here designated the lectotype - is quite well preserved, apart from the largely missing dorsal surface of the opisthosoma. It is unclear whether this was always the case (see below), or whether the fossil has became damaged since its original description. The other specimen - here designated the paralectotype - is by comparison of little value, being set deep in the cracked and oxidised matrix and only referable to this species by virtue of some hints of characteristic tuberculation on the body. It is not figured here.

Nemastoma denticulatum was transferred to Mitostoma Roewer, 1951 by Staręga (1976, 2002). As in the original diagnosis of Mitostoma, the amber fossil bears isolated rows of slightly mushroom-shaped tubercles which vaguely form a pair of projections at their distal margins and sometimes merge together as a continuous band: i.e. Roewer's processuli ancoriformis or "Zweizackzähnchen" (= double-pointed teeth) or Martens" "Brückendorn" (= bridging thorns). However, compared to Roewer's (1951, figs 68-77) illustrations it is worth mentioning that there are only simple procurved rows of processuli preserved behind the ocular tubercle in the fossil, while many living Mitostoma species show a more complex morphology; specifically with a prominent row of processuli approaching, and traversing, the ocular tubercle. Koch \& Berendt's (1854, fig. 98) original drawing, reproduced by Staręga (1976), shows the rows being much straighter than in the actual type specimen and illustrates well the danger of not referring back to the original material. Furthermore, although the dorsal surface of the opisthosoma in the lectotype is incomplete the number of procurved rows of processuli is betrayed at the lateral margins and seems to have been no more than four in total - the ornament thus only reaching about halfway down the length of the body. In described Mitostoma species there tend to be more rows and this more restricted ornament in the fossil is also suggestive of the probably closely-related Carinostoma Kratochvíl, 1958. Bearing in mind the variability of structural ornament among the living Nemastomatidae, Martens (1978: 134) preferred to separate Mitostoma and Carinostoma on genital rather than the somatic characters in Kratochvíl's original diagnosis. Genital characters are, thus far, not available in Baltic amber harvestmen, but Martens' comments should caution against raising a new (fossil) genus based solely on different patterns of dorsal ornament.

Staręga's (1976) transfer of $N$. denticulatum to Mitostoma, is thus tentatively accepted. This fossil species is perhaps closest to Roewer's (1951) "IV. Gruppe" whose members were defined by rows of more-or-less isolated processuli without strong keels underlying them; a condition which approximates that seen in the fossil. Staręga (1976) also referred Roewer's Baltic amber species N. succineum Roewer, 1939 to M. denticulatum; albeit without discussion. This Roewer type could not be traced (see above) and his original backlit photograph simply shows the animal in outline and lacks useful details. Nevertheless its assignment to Mitosoma seems justified since even in his original description (Roewer 1939: 4) he commented on the similarity of his amber fossil to N. chrysomelas (Hermann, 1804). This would later become (Roewer 1951) the type species of his new genus Mitostoma.

Significantly, there is no indication of spines in Koch \& Berendt's original description and reconstruction. They refer (p. 98) simply to "Körnchen" ornamenting the opisthosoma; albeit possibly derived from this broken holotype specimen. Roewer (1939) explicitly described an opisthosoma in N. succineum without spines: "Die Tergite des Abdomens sind unbewehrt ...". This is important because there appears to be undescribed nemastomatid material (e.g. Weitschat \& Wichard 2002, pl. 12f) which strongly resembles $M$. denticulatum in having processuli, but which also has a series of prominent spines in the region of the opisthosoma tantalisingly missing in the $M$. denticulatum holotype (Figs 5A,6A-B). 
Thus there appear to be Mitostoma-like harvestmen in Baltic amber both with and without prominent opisthosomal spines. Provisionally, the name M. denticulatum (with $N$. succineum as its synonym) can be used for those fossils without spines towards the back end of the opisthosoma - even when the holotype is equivocal on this character - while the undescribed spiny fossils may deserve a new species name. This will have to be addressed in future papers.

\section{Histricostoma Kratochvíl, 1958}

\section{Histricostoma (?) tuberculatum (Koch \& Berendt, 1854)}

Figs 5B, 6C

1845 Nemastoma tuberculatum Berendt: 872. (nomen nudum)

1854 Nemastoma tuberculatum Koch \& Berendt: 97-98, pl. 11: fig. 97.

1856 Nemastoma tuberculatum. - Giebel, 474-475.

1891 Nemastoma tuberculatum. - Scudder: 275.

1962 Nemastoma tuberculatum. - Dubinin: 481: fig. 1379.

1976 Histricostoma (?) tuberculatum. - Staręga, 45-46, fig. 78.

1978 Nemastoma tuberculatum. - Larsson: 143, fig. 52.

1982 Nemastoma tuberculatum. - Keilbach: 191.

1993 Nemastoma tuberculatum. - Selden: 306.

1993 Nemastoma tuberculatum. - Spahr: 21.

1997 Nemastoma tuberculatum. - Krzemińska \& Krezemiński: 97 , fig. 140.

2002 Histricostoma (?) tuberculatum. - Staręga: 602-603.

Holotype. MfN, Berendt collection, repository number 7248 .

Type locality and stratum. Baltic amber (Palaeogene, Eocene); precise locality unclear.

Diagnosis. Fossil Histricostoma with four pairs of small, raised tubercles on the opisthosoma arranged in sub-parallel rows.

Description. A relatively complete and wellpreserved specimen. Body more or less pearshaped, length $1.88 \mathrm{~mm}$, maximum width $1.38 \mathrm{~mm}$. No external differentiation into prosoma and opisthosoma. Ocular tubercle present, but poorly defined. Opisthosoma bears four pairs of short, blunt dorsal spines, forming two rows c. $0.2 \mathrm{~mm}$ apart. Chelicerae present, but largely indistinct. Pedipalps with elongate femora bearing numerous, mostly inward-facing, setae. More distal articles hidden within the matrix. Legs more or less complete, slender and still articulated to the body. Legs 1-4 with approximate lengths of 4.6, 9.6, 4.9 and $7.5 \mathrm{~mm}$ respectively, i.e. a leg formula of (from longest to shortest): $2,4,3,1$. Leg articles with occasional short setae. Leg 1 femora with possible hints of pseudoarticulation. Tarsi divided distally into multiple tarsomeres (not resolvable in all legs) with at least nine in leg 4. Tarsus ends in a single curved claw.

Remarks. The holotype has the typical nemastomatid morphology of a body with almost complete fusion of the prosoma and opisthosoma. Staręga's $(1976,2002)$ tentative referral to the extant genus Histricostoma Kratochvíl, 1958 based primarily on the paired, slender, pillar-like spines on the opisthosoma is supported. However, it should be noted that slender opisthosomal spines can occur in other extant genera such as Mediostoma Kratochvíl, 1958 and (the typically quite large) Paranemastoma Redikorzew, 1936; thus an unequivocal referral of the fossil to Histricostoma is probably premature (Jochen Martens, pers. comm. 2005). Recent Histricostoma species are found in central and southern Europe, including Turkey (see also Staręga 2002). One typically Alpine species can occur in the southern states of Germany (Bavaria, Baden-Württemberg) (Blick \& Komposch 2004), but its presence here is something of an exception. The fossil example from the Baltic region is from further north than the present day range of the genus.

\section{Nomina dubia}

\section{Cheiromachus Menge, 1854}

\section{Cheiromachus coriaceus Menge, 1854}

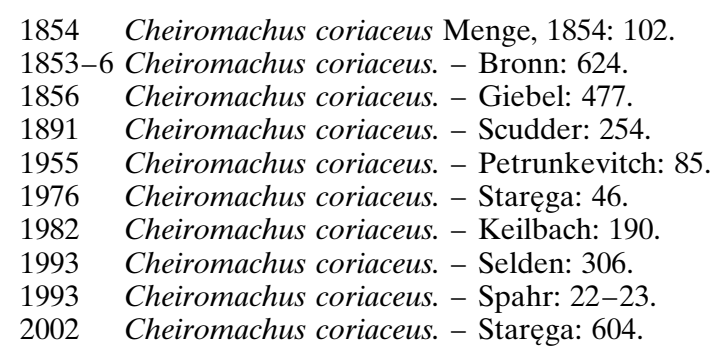

1854 Cheiromachus coriaceus Menge, 1854: 102.

1853-6 Cheiromachus coriaceus. - Bronn: 624.

1856 Cheiromachus coriaceus. - Giebel: 477.

1891 Cheiromachus coriaceus. - Scudder: 254

1955 Cheiromachus coriaceus. - Petrunkevitch: 85.

1976 Cheiromachus coriaceus. - Staręga: 46.

1982 Cheiromachus coriaceus. - Keilbach: 190.

1993 Cheiromachus coriaceus. - Selden: 306.

1993 Cheiromachus coriaceus. - Spahr: 22-23.

2002 Cheiromachus coriaceus. - Staręga: 604.

Holotype. Formally in Danzig (= Gdańsk, Poland), current whereabouts unknown.

Type locality and horizon. Baltic amber (Palaeogene, Eocene); precise locality unclear.

Re marks. This species is significant as the only Baltic amber harvestman originally assigned to an extinct genus. While the Baltic amber laniatorid, P. nemastomoides, differs sufficiently from living taxa to warrant a new, fossil genus (Ubick \& Dunlop 2005), all other Baltic harvestmen have thus far been assigned to extant genera. In the footnotes to the original description of P. nemastomoides, Menge (1854) suggested that this laniatorid should effectively be placed in a 
different suborder (Eupnoi) via the genus Acantholophus C. L. Koch, 1839 (preoccupied, now Lacinius Thorell, 1876 - see discussion in Crawford 1992). Later (Menge 1856:11), he changed his mind and suggested that P. nemastomoides was "probably identical" to Cheiromachus coriaceus Menge, 1854, although without an illustration of the latter species this assignment is difficult to test. Staręga $(1976,2002)$ regarded the systematic position of Cheiromachus as uncertain within the Phalangiidae. In an attempt to resolve this situation, Menge's (1854: 102) original diagnosis - reproduced by Bronn (1853-6) and as a shorter English translation by Petrunkevitch (1955) - is retranslated here as follows.

"A new genus Cheiromachus distinguished by peculiar pedipalps: the first article short and inversely conical. The second article very thickly curved backwards, laterally somewhat pressed together, at the lower surface pustulate, rather long. The third article inversely conical, much thinner and half as long. The fourth is short and spindle-like. The final article thin and wiry. The end, however, is missing. Likewise all limbs up to some of the thighs missing. Body complete. Clearly visible is the pustulate dorsal surface of the body. The pustules on the raised, almost wart-like ocular tubercle stronger, the ventral surface smooth. Length over $2^{\prime \prime \prime}$. Abdomen width $1^{\prime \prime \prime}$. Ch. coriaceus. M."

A number of extant genera exhibit a comparably pustulate body and/or ocular tubercle, but these 'peculiar' thickenings on the pedipalps described by Menge cannot be readily matched to any known (living) genus (Jochen Martens, pers. comm. 2005). Conceivably there is an extinct amber harvestman genus with diagnostic pedipalps and future work may recover specimens comparable to Menge's description. However, in the absence of a type specimen or illustration it is probably best to place Cheiromachus coriaceus for the time being as a nomen dubium of uncertain familial affinity.

\section{Phalangium succineum Presl, 1822}

1822 Phalangium succineum Presl: 209.

1891 Phalangium succineum. - Scudder: 279.

Holotype. Repository unknown; according to Scudder (1891) from "Prussian" (i.e. Baltic) amber. Jan Svatopluk Presl is a well-known figure in Czech botanical nomenclature and also did (unpublished) work on fossil cephalopods. His amber descriptions were published in Prague, but there is no record of amber material associated with him in the palaeontological collections of National Museum Prague (Vojtěch Turek, pers. comm. 2005). The whereabouts of his type mate- rial thus remains unclear and is probably lost (Wolfgang Weitschat, pers. comm. 2005). Presl's work incidentally is the oldest historical record I am aware of offering formal descriptions and names of fossil arachnids. It is thirteen years older than the Coal Measures scorpion Cyclopthalmus senior Corda, 1835 which Petrunkevitch (1953: 24), for example, cited as the (historically) oldest fossil arachnid to have been described.

Type locality and horizon. Baltic amber (Palaeogene, Eocene); precise locality unclear.

Remarks. Apart from being listed in Scudder (1891) the name has been overlooked by all subsequent authors. The original Latin description of a c. $4 \mathrm{~mm}$ long animal is very general and could apply to any number of taxa. No figure was included. The fact that Presl described long, dark legs, "Pedis fusci, longi ...", a quadratic prosoma, "Thorax quadrangulus ...", and - significantly as a separate body region - an elongate, oval opisthosoma, "Abdomen oblongum, ovoideum...", raises the possibility that Presl mistook a spider for a harvestman. Opiliones generally do not have an elongate opisthosoma and the basic body shape he described would be consistent with certain spiders like, for instance, the long-legged Pholcus which is sometimes confused with harvestmen by the general public. Without a specimen or illustration with which to confirm the identity and affinities of this taxon, Phalangium succineum Presl, 1822 should probably be regarded as a nomen dubium.

\section{Acknowledgements}

I thank Christian Neumann (Berlin) and Helmut Mayr (Munich) for access to material in their care and Axel Schönhofer (Mainz) and Plamen Mitov (Sofia) for valuable comments on harvestman taxonomy. Barbara Kosmowska-Ceranowicz (Warsaw), Norbert Vávra (Vienna), Vojtěch Turek (Prague) and Wolfgang Weitschat (Hamburg) kindly offered information about known or likely type repositories. Jochen Martens (Mainz) and Christian Komposch (Graz) made numerous helpful observations, both through correspondence and their reviews of the manuscript.

\section{References}

Banks, N. 1892. A new genus of Phalangiidae. - Proceedings of the Entomological Society of Washington 2 (2): 249-251.

- 1893. The Phalanginae of the United States. - The Canadian Entomologist 25: 205-211.

Berendt, G. C. 1830. Die Insekten im Bernstein, ein Beitrag zur Thiergeschichte der Vorwelt. 30 pp., Danzig.

- 1845. Die im Bernstein befindlichen organischen Reste der Vorwelt, gesammelt, in Verbindung mit Mehren bearbeitet und herausgegeben. - Neues Jahrbuch für Mineralogie, Geognosie, Geologie und Petrefakten-Kunde 1845: 864-879. 
Bishop, S. C. \& Crosby, C. R. 1924. A fossil species of Caddo (Opiliones) from the Baltic amber, and its living relatives. - Bulletin of the New York State Museum 253: $83-84$.

Blick, T. \& Komposch, C. 2004. Checkliste der Weberknechte Mittel- und Westeuropas./Checklist of the harvestmen of Central and Western Europe (Arachnida: Opiliones). Internet: http://www.arages.de/files/checklist2002opiliones.pdf. 6 pp.

Bonnet, P. 1958. Bibliographia Araneorum, Tome II (4me partie N-S). pp. 3027-4230. Douladoure, Toulouse.

Bronn, H. G. 1853-6. Lethaea Geognostica. 3. Band. 4 (IV). 1130 pp., E. Schweitzerbart'sche, Stuttgart.

Cokendolpher, J. C. 1984. Homonyms of American and European Leiobunum (Opiliones, Palpatores, Leiobuninae). Journal of Arachnology 12: 118-119.

Corda, A. J. C. 1835. Ueber den in der Steinkohlenformation bei Chomle gefundenen fossilen Scorpion. - Verhandlung der Gesellschaft des Vaterländischen Museums Böhmen 1835: 36.

Crawford, R. L. 1992. Catalogue of the genera and type species of the harvestman superfamily Phalangioidea (Arachnida). - Burke Museum Contributions in Anthropology and Natural History 8: 1-60.

Doleschall, L. 1852. Systematisches Verzeichnis der im Kaiserthum Österreich vorkommenden Spinnen. - Sitzungsberichte der Mathematisch-Naturwissenschaftlichen Classe der Kaiserlichen Akademie der Wissenschaft 9: 622-651.

Dresco, E. 1970. Recherches sur la variabilité et la phylogénie chez les Opiliones du genre Ischyropsalis C. L. Koch (Fam. Ischyropsalidae), avec la création de la famille nouvelle des Sabaconidae. - Bulletin du Muséum National d'Histoire Naturelle, $2^{\mathrm{e}}$ Serie 41: 1200-1213.

Dubinin, V. B. 1962. Klass Arachnida. Paukoobraznye. In Rodendorf, B. B. (ed). Osnovy Paleontologii. Spravočnik dlja Paleontologov i Geologov SSSR: Clenistogii, Trachejnye i Chelicerovye: pp. 474-516., Akademija Nauk SSSR, Moskova.

Dunlop, J. A. in press. Palaeontology. In Pinto da Rocha, R., Machado, G. \& Giribet, G. (eds). The Harvestmen: The Biology of Opiliones. Harvard University Press, Cambridge MA.

Dunlop, J. A. \& Giribet, G. 2003. The first fossil cyphophthalmid (Arachnida, Opiliones) from Bitterfeld Amber Germany. - Journal of Arachnology 31: 371-378.

Geoffroy, E. L. 1762. Histoire Abregée des Insectes Qui se Trouvent aux Environs de Paris; dans La quelle ces Animaux Sont Rangés Suivant un Ordre Méthodique, vol. 2. Durand, Paris.

Giebel, C. G. A. 1856. Fauna der Vorwelt mit steter Berücksichtigung der lebenden Thiere, Bd. 2, Abth. I. Die Insecten und Spinnen der Vorwelt, mit steter Berücksichtigung der lebenden Insecten und Spinnen, monographisch dargestellt. 512 pp., Brockhaus, Leipzig.

Hansen, H. J. \& Sørensen, W. 1904. On two orders of Arachnida. 178 pp., Cambridge, Cambridge University Press.

Hermann, J. F. 1804. Mémoire Apterologique. 144 pp., F. G. Levrault, Strasbourg.

Hillyard, P. D. 2004. Editorial. Ocularium No. 5 In Newsletter of the British arachnological Society 99: 14 .

Keilbach, R. 1982. Bibliographie und Liste der Arten tierischer Einschlüsse in fossilen Harzen sowie ihre Aufbewahrungsorte. Teil 1. - Deutsche Entomologische Zeitschrift 29: 129-286.

Koch, C. L. 1839. Übersicht des Arachnidensystems 2: $23-38$.

Koch, C. L. \& Berendt, G. C. 1854. Die im Bernstein befindlichen Crustaceen, Myriapoden, Arachniden und Apteren der Vorwelt. 124 pp., Edwin Groening, Berlin.

Kosmowska-Ceranowicz, B. (ed.) 2001. The Amber Treasure Trove, Part 1.97 pp., Museum of the Earth Documentary Studies, No. 18, Warsaw. [Also published in Polish]
Kratochvíl, J. 1958. Höhlenweberknechte Bulgariens (Palpatores - Nemastomatidae). - Acta Academiae Scientiarum Čechoslovenicae Basis Brunensis 30: 523-576.

Krzemińska, E. \& Krezemiński, W. 1997. Les Fantomes de l'Ambre. Insectes fossiles dans l'ambre de la Baltique. 142 pp., Musée d'Histoire naturelle de Neuchâtel, Suisse, Neuchâtel.

Kury, A. 2003. Checklist of the valid opilionid genera of the world. http://acd.ufrj.br/mndi/Aracnologia/checklaniator.htm

Larsson, S. G. 1978. Baltic amber - a palaeobiological study. Entomonograph, Volume 1. 192 pp., Klampenborg, Denmark.

Latreille, P. A. 1802. Histoire Naturelle des Fourmis, et recueil de mémoires et d'observations sur les abeilles, les araignées, les faucheurs, et autres insectes. 445 pp., Paris.

Linnaeus, C. 1758. Systema Naturae, $10^{\text {th }}$ edition, vol. 1 . Holmiae, Salvii.

- 1761. Fauna Suecica Sistens Animalia Sveciae Regni: Mammalia, Aves, Amphibia, Pisces, Insecta, Vermes. $2^{\text {nd }}$ edition. Holmiae, Stockholm.

Lucas, M. H. 1860. Note sur le Scotolemon leprieurii, nouvelle espèce d'Arachnide Trachénne qui habite la grotte de l'ours (Buco del Orso) en Lombardie. - Annales de la Société Entomologique de France (3) 8: 984-988.

Martens, J. 1978. Spinnentiere, Arachnida, Weberknechte, Opiliones. Die Tierwelt Deutschlands. 64. Teil. 464 pp., Gustav Fischer Verlag, Jena.

Menge, A. 1854. Footnotes In Koch, C. L. \& Berendt, G. C. Die im Bernstein befindlichen Crustaceen, Myriapoden, Arachniden und Apteren der Vorwelt. 124 pp., Edwin Groening, Berlin.

- 1856. Lebenszeichen vorweltlicher, im Bernstein eingeschlossener Thiere. Programm, womit zu der am Montag den 17. März 1856 von 8 1/2 Uhr Vorm. und 2 1/2 Uhr Nachm. an stattfindenden öffentlichen Prüfung der Schüler der Petrischule, 32 pp., Danzig.

Petrunkevitch, A. I. 1953. Paleozoic and Mesozoic Arachnida of Europe. - Memoirs of the Geological Society of America 53: $1-128$.

- 1955. Arachnida. 42-162. In Moore, R. C. (ed.) Treatise on Invertebrate Paleontology, Part P, Arthropoda 2. 181 pp., Geological Society of America and University of Kansas Press, Lawrence, Kansas.

- 1958. Amber spiders in European collections. - Transactions of the Connecticut Academy of Arts and Science 41: $97-400$.

Presl, J. S. 1822. Additamenta ad faunam protogaeam, sistens descriptiones aliquot animalium in succino inclusorum. In Presl, J. S. \& Presl, C. B. (eds). Deliciae Pragenses Historiam Naturalem Spectantes. Tome I. viii +244 pp., Calvae, Pragae [= Prague].

Redikorzev, V. 1936. Beiträge zur Opilioniden-Fauna von USSR. - Travaux de l'Institut zoologique de l'Academie des sciences de l'URSS 3: 33-57.

Roewer, C.-F. 1923. Die Weberknechte der Erde. 1116 pp., Gustav Fischer, Jena.

- 1939. Opilioniden im Bernstein. - Palaeobiologica 7 (1): $1-4$.

- 1951. Über Nemastomatiden. Weitere Weberknechte XVI. - Senckenbergiana 32: 95-153.

Scudder, S. H. 1891. Index to the known fossil insects of the world including myriapods and arachnids. - Bulletin of the United States Geological Survey 71: 1-774.

- 1885. 3. Classe. Arachnoidea. Spinnen. Skorpione. 732746. In Zittel, K. A. (ed.) Handbuch der Palaeontologie, I Abt. II Band. 893 pp., R. Oldenbourg, München \& Leipzig.

- 1886. In Zittel, K. A. \& Barrois, C. E. (eds) Traité de Paléontologie. I, Paleozoologie, II, Mollusca et Arthropoda. 897 pp., Doin, Paris.

Shear, W. A. 1975. The opilionid family Caddidae in North America, with notes on species from other regions (Opi- 
liones, Palpatores, Caddoidea). - Journal of Arachnology 2: $65-88$.

Simon, E. 1879. Opiliones Sund. - Les Arachnides de France 7: $116-332$

- 1909. Étude sur les Arachnides recueillis au Maroc par M. Martínez de la Escalera en 1907. Memorias de la Sociedad Española de Historia Natural, Madrid 6: $5-43$.

Sphar, U. 1993. Ergänzungen und Berichtigungen zu R. Keilbachs Bibliographie und Liste der Bernsteinfossilien Verschiedene Tiergruppen, ausgenommen Insecta und Araneae. - Stuttgarter Beiträge zur Naturkunde, Serie B (Geologie und Paläontologie) 194: 1-77.

Staręga, W. 1976. Opiliones Kosarze (Arachnoidea). Fauna Polski, Tom 5. 196 pp., Polska Akademia Nauk, Instytut Zoologii, Warszawa.
- 2002. Baltic amber harvestmen (Opiliones) from Polish collections. - Annales Zoologici 52: 601-604.

Sundevall, J. C. 1833. Conspectus Arachnidium. C. F. Berling, Londini Gothorum.

Thorell, T. 1876. Sopra alcuni Opilioni (Phalangidea) d'Europa e dell'Asia occidentale, con un quadro dei generi europei di quest'Ordine. - Annali del Museo Civico di Storia Naturale, Genova 8: 452-508.

Ubick, D. \& Dunlop, J. A. 2005. On the placement of the Baltic amber harvestman Gonyleptes nemastomoides Koch \& Berendt, 1854, with notes on the phylogeny of Cladonychiidae (Opiliones: Laniatores: Travunioidea). - Mitteilungen aus dem Museum für Naturkunde, Berlin Geowissenschaftliche Reihe 8: 75-82.

Weitschat, W. \& Wichard, W. 2002. Atlas of plants and animals in Baltic amber. 256 pp., Verlag Dr. Pfeil, München. 